\title{
Effect of Peppermint Oil on Serum Lipid Peroxidation and Hepatic Enzymes after Immobility Stress in Mice
}

\author{
Abdoljalal Marjani*, ${ }^{1}$, Reza Rahmati ${ }^{2}$, Azad Reza Mansourian ${ }^{1}$ and Gholamreza Veghary ${ }^{1}$ \\ ${ }^{I}$ Department of Biochemistry and Biophysics and Nutrition, Biochemistry and Metabolic Disorder Research Center, \\ ${ }^{2}$ Department of Physiology, Faculty of Medicine, Golestan University of Medical Sciences, Golestan province, Gorgan, \\ Iran
}

\begin{abstract}
This study was undertaken to determine the influences of various doses of peppermint oil on the hepatic enzymes, alanine transaminase, apartate tranaminase, alkaline phosphotase and gamma glutamyl transferase and the level of malondialdehyde in the serum of mice with and without immobility stress. The mice exposed to drink water, 0.9, 27 and $60 \mathrm{mg} / \mathrm{kg}$ peppermint oil from the days 1 to 5 for a period of $4 \mathrm{~h}$ before and after immobility stress. Serum MDA increased in treatment group II, III and IV after immobility stress. There was a significant decrease in ALT in treatment group III and IV after immobility stress. There were also significant decreases in ALP and GGT in treatment group IV after immobility stress. This result may suggest that, MDA level is higher in immobilization stress group than in the unimmobilized animals in serum and this results show that enzyme activities decreased after immobilization stress.
\end{abstract}

Keywords: Peppermint oil, lipid peroxidation, hepatic enzymes, immobility stress.

\section{INTRODUCTION}

The currently observed rapid increase in consumption of herbal remedies worldwide has been stimulated by several factors, including the notion that all herbal products are safe and effective [1-3]. However, over the past decade, several news-catching episodes in developed communities indicated adverse effects, sometimes life-threatening, allegedly arising consequential to taking herbal products or traditional medicines from various ethnic groups $[4,5]$. In some cases, adulteration, inappropriate formulation, or lack of understanding of plant and drug interactions or uses has led to adverse reactions that are sometimes life-threatening or lethal to patients [6-8]. Peppermint (Mentha piperita L.) is a perennial herb native to Europe, naturalized in the northern USA and Canada, and cultivated in many parts of the world. A hybrid of spearmint ( $M$ spicafa $\mathrm{L}$.) and water mint (M. aquatica $L$.), peppermint grows particularly well in areas with high waterholding capacity soil. Peppermint leaves (fresh and dried) and the essential oil extracted from the leaves are used in many foods, cosmetic and pharmaceutical products. The chemical components of peppermint leaves and oil vary with plant maturity, variety, geographical region and processing conditions [9-13]. About $80 \%$ of the world population currently relies on indigenous or traditional medicines for their primary health needs, and most of this therapy involves the use of plant extracts, often in aqueous solutions [14]. Of the plant-based foods used as medicines, none have received more attention as a group than herbal remedies [15]. The use of herbal preparations, typically prepared by steeping or heating crude plant material, has prevailed for centuries and

*Address correspondence to this author at the Department of Biochemistry and Biophysics and Nutrition, Biochemistry and Metabolic Disorder Research Center Golestan province, Gorgan, Iran; Tel: 0981714421651; Fax: 00981714440225; E-mail: abdoljalal@yahoo.com healthcare providers in Europe and Asia today often prescribe herbal teas. However, such practices are largely based on folklore and schools of traditional medicine rather than evidence-based research. A large and increasing percentage of people consume herbal medicines and there is a universally acknowledged need for more studies of adverse effects, including liver toxicity [16]. Peppermint oil has been used externally (e.g. for insect bites). However, it is also administered orally for the treatment of irritable bowel syndrome [17]. Peppermint oil consists of many components, with menthol being a major constituent. Most reports of toxic effects due to the use of herbal medicines and dietary supplements are associated with hepatotoxicity has been published in medical literature. On the basis of various case reports, liver injury from herbal remedies has ranged from mild elevations of liver enzymes to fulminated liver failure [18]. The effects of components of peppermint oil have been investigated in rats $[19,20]$ that were administrated menthol or menthone (200-800 mg/kg) for 28 days. Histopathological liver changes and changes in liver function were found in those studies. Lipid peroxidation has damaging effects on liver cell membrane. The extent of lipid peroxidation was measured using a technique based on the thiobarbituric acid reactive substance (TBARS) assay that detects malondialdehyde (MDA), an end product of peroxidative decomposition of polyeonic fatty acids in in vitro systems [21]. The purpose of this study was to examine the effect of peppermint oil on the activity of several liver enzymes and serum MDA in male albino rats, under normal conditions and during stress (immobilization). This is a relatively straight forward experimental study.

\section{MATERIALS AND METHODOLOGY}

The study was performed in 2010 on forty-eight male albino mice weighing $27.30-28.30 \mathrm{~g}$ of 3-4 postnatal weeks 
(provided from the Iranian Pasteur Institute) in the Faculty of Medicine, Biochemistry and Metabolic Disorder Research Center, Gorgan University of Medical Sciences. The animals were kept in special cages, with standard dimension in a room with $12 \mathrm{~h}$ rotation of being in light and darkness at $20 \pm 2{ }^{\circ} \mathrm{C}$, till the time of experiment. The animals were allowed to have drinking water and prepared food (Dam Pars Production), and they went only once under experimental procedure. $0.5 \mathrm{ml}$ peppermint oil was injected to animals every day at 8.30 AM. Peppermint oil is purchased form Barij Essence Pharmaceutical Co., Kashan, Iran. Alcoholic extract of Barij peppermint contained $50 \%$ of mentol, menton and mentol acetate. To dilute the peppermint extract, physiological saline was used as carrier. Different concentration of peppermint extracts were chosen on the bases of pilot tests. The animals were divided into 8 groups of 10 mice. The mice were randomly divided into two equal groups on the basis of the differences in the concentrations of peppermint oil. Each group was subdivided into four on the basis of drinking water, $0.9,27$ and $60 \mathrm{mg} / \mathrm{kg}$ peppermint oil, as follows:

\section{Without Immobility Stress}

Treatment Group (Group I) received only drinking water, Treatment Group (Group II) received $0.9 \mathrm{mg} / \mathrm{kg}$ peppermint oil, Treatment Group (Group III) received $27 \mathrm{mg} / \mathrm{kg}$ peppermint oil, Treatment Group (Group IV) received $60 \mathrm{mg} / \mathrm{kg}$ peppermint oil.

\section{Under Immobility Stress}

Treatment Group (Group I) received only drinking water, Treatment Group (Group II) received $0.9 \mathrm{mg} / \mathrm{kg}$ peppermint oil, Treatment Group (Group III) received $27 \mathrm{mg} / \mathrm{kg}$ peppermint oil, Treatment Group (Group IV) received $60 \mathrm{mg} / \mathrm{kg}$ peppermint oil.

It was found by means of a digital scale that the mean weight for each group was $27.75 \pm 0.31 \mathrm{gr}$ (I), $27.85 \pm 0.32 \mathrm{gr}$ (II), 27.89 \pm 0.30 (III) and $27.84 \pm 0.35$ gr (IV). The experimental groups were exposed to immobility stress every morning from the days 1 to 5 for a period of $4 \mathrm{~h}$. The immobility stress was produced by plastic tubes (self made) with length and width of $15 \mathrm{~cm}, 15 \mathrm{~cm}$ respectively, and while in the tube, the animals was able to breathe smoothly and properly and were under no physical strain. The animals prior to surgery made unconscious by the combination of ketamine $10 \%(100 \mathrm{mg} / \mathrm{kg})$ and xylazine $2 \%(10 \mathrm{mg} / \mathrm{kg})$ which were injected through peritoneum. At the end of the $5^{\text {th }}$ day of the experiment, the thorax of the mice was opened and 2-3 ml of blood was collected from the heart of each mouse under anesthesia. The blood samples were centrifuged at $3000 \mathrm{rpm}$ for $10 \mathrm{~min}$ after waiting for $10 \mathrm{~min}$ after waiting $15 \mathrm{~min}$ at room temperature. Serum was collected and stored at $-20^{\circ} \mathrm{C}$. The time of experiments was between $10 \mathrm{am}-3$ pm each day. Serum lipid peroxidation (expressed as malondialdehyde) examined by Satoh method [22] and hepatic enzymes ALT, AST, ALP and GGT examined by Commercial laboratory kits [23-25] and using specterophotometry and photometry techniques in Biochemistry and Metabolic Disorder Research Center. Experimental results concerning this study were evaluated by using SPSS v.16 and expressed as Mean \pm SD. Also independent and paired t- test and ANOVA Post-huc was performed to determine the difference between groups. $\mathrm{P}<0.05$ was considered significant.

\section{RESULTS}

Findings of serum MDA, ALT, AST, GGT and ALP are reported in Tables $\mathbf{1}$ and $\mathbf{2}$. Table $\mathbf{1}$ and $\mathbf{2}$ contain mean \pm SD of MDA, ALT, AST, ALP and GGT values for mice exposed to drink water, $0.9,27$ and $60 \mathrm{mg} / \mathrm{kg}$ peppermint oil from the days 1 to 5 for a period of $4 \mathrm{~h}$ before and after immobility stress. Table 1 shows (before immobility stress) that the mean value of serum MDA and ALP decreased and serum ALT, AST and GGT increased in comparison with treatment group I. There was significant decreases in MDA in treatment group III when compared with treatment group I $(\mathrm{p}=0.005)$. There was also significant decreases in MDA in treatment group IV when compared with treatment group I, II and III $(\mathrm{p}<0.001)$. There was significant decreases in ALP in treatment group IV when compared with treatment group I $(\mathrm{p}=0.020)$ and there was significant increases in AST in treatment group III and IV when compared with treatment group I $(\mathrm{p}=0.001)$ and II $(\mathrm{p}<0.001)$. There was no significant difference in ALT and GGT in all treatment groups (Table 1). Table 2 shows (after immobility stress) that the mean of serum MDA, ALT and ALP decreased and serum AST and GGT increased in comparison with treatment group I. There was significant decreases in MDA in treatment group IV when compared with treatment groups I $(\mathrm{p}=0.001)$, II $(\mathrm{p}=0.006)$ and III $(\mathrm{p}=0.024)$ and significant decreases in ALP when compared with treatment group I $(\mathrm{P}=0.030)$. There was significant increases in AST in treatment group III and IV when compared with treatment group I $(\mathrm{p}=0.032$ and $\mathrm{p}=0.001$ ) respectively. There was no significant difference in ALT and GGT in all treatment groups (Table 2). Table 3 shows the comparison of serum MDA levels and hepatic enzymes before and after immobility stress. The mean of serum MDA significantly increased in treatment group II, III and IV after immobility stress $(\mathrm{P}=0.026, \mathrm{P}=0.001$ and $\mathrm{P}<0.001$ respectively). There was significant decreases in ALT in treatment group III and IV after immobility stress $(\mathrm{p}=0.001$ and $\mathrm{p}<0.001$ respectively). There were also significant decrease in ALP and GGT in treatment group IV after immobility stress $(p=0.011$ and $p=0.011$ respectively).There was no significant difference in all other treatment groups.

\section{DISCUSSION AND CONCLUSION}

The results of this study indicate that there has been lower MDA production during peppermint oil metabolism so that even the increase in AST, ALT and GGT activities could eliminate the MDA. A significant decrease in MDA level in treatment group III and IV also supported this idea. The study revealed that MDA levels were found to have decreased during the use of higher doses of peppermint oil (27 and $60 \mathrm{mg} / \mathrm{kg}$ ) and the low amounts of MDA have not been shown to inhibit the activities of AST, ALT and GGT, whereas there have been changes in ALP activity which were given $60 \mathrm{mg} / \mathrm{kg}$ peppermint oil. The data we have interpreted as a low amount of MDA formation could be eliminated with the use of higher doses of peppermint oil $(27$ and $60 \mathrm{mg} / \mathrm{kg})$. These results indicate that low levels of MDA formation 
Table 1. Serum levels of Alanine Transaminase (ALT), Apartate Tranaminase (AST), Alkaline Phosphotase (ALP) and Gamma Glutamyl Transferase (GGT) in Treatment Groups Without Immobility Stress

\begin{tabular}{|c|c|c|c|c|c|}
\hline GGT $($ IU/L) & ALP $(\mathbf{I U} / \mathbf{L})$ & AST $(\mathbf{I U} / \mathbf{L})$ & ALT $($ IU/L) & MDA (nmol/ml) & Groups \\
\hline \hline $13 . .04 \pm 4.93$ & $155.20 \pm 37.12$ & $89.10 \pm 28.12$ & $95.20 \pm 36.90$ & $1.91 \pm 0.20$ & Treatment Group I \\
\hline $15.42 \pm 8.35$ & $132.20 \pm 18.50$ & $90.40 \pm 27.50$ & $115.85 \pm 40.79$ & $1.85 \pm 0.08$ & Treatment Group II \\
\hline $17.43 \pm 7.59$ & $129.0 \pm 36.54$ & $136.60 \pm 12.98^{3}$ & $121.20 \pm 31.18$ & $1.70 \pm 0.07^{1}$ & Treatment Group III \\
\hline $18.99 \pm 6.51$ & $116.60 \pm 10.66^{5}$ & $157.20 \pm 28.79^{4}$ & $127.50 \pm 36.76$ & $1.40 \pm 0.13^{2}$ & Treatment Group IV \\
\hline
\end{tabular}

Values are means \pm SD. Calculated from $\mathrm{n}=10$ in each group. ${ }^{1} p=0.005$ compared to treatment Group I (control group) (ANOVA), ${ }^{2} p<0.001$ compared to treatment Group I (control group), II and III (ANOVA), ${ }^{3} p=0.001$ and ${ }^{4} p<0.001$ compared to treatment Group I (control group) and II (ANOVA), ${ }^{5} p=0.020$ compared to treatment Group I (ANOVA), Treatment Group I (TG I) received drink water daily for 5 day (control group)., Treatment Group II (TG II) received $0.9 \mathrm{mg} / \mathrm{kg}$ peppermint oil daily for 5 days, Treatment Group III (TG III) received $27 \mathrm{mg} / \mathrm{kg}$ peppermint oil daily for 5 day, Treatment Group IV (TG IV) received $60 \mathrm{mg} / \mathrm{kg}$ peppermint oil daily for 5 day.

Table 2. Serum Levels of Alanine Transaminase (ALT), Apartate Tranaminase (AST), Alkaline Phosphotase (ALP) and Gamma Glutamyl Transferase (GGT) in Treatment Groups with Immobility Stress

\begin{tabular}{|c|c|c|c|c|c|}
\hline GGT $($ IU/L) & ALP $($ IU/L) & AST (IU/L) & ALT (IU/L) & MDA (nmol/ml) & Groups \\
\hline \hline $10.61 \pm 4.19$ & $135.60 \pm 41.04$ & $76.60 \pm 22.48$ & $104.20 \pm 61.91$ & $2.13 \pm 0.40$ & Treatment Group I \\
\hline $12.41 \pm 5.35$ & $120.0 \pm 30.42$ & $102.0 \pm 13.98$ & $99.80 \pm 29.50$ & $2.05 \pm 0.24$ & Treatment Group II \\
\hline $12.71 \pm 4.59$ & $103.10 \pm 37.60$ & $123.30 \pm 37.89^{3}$ & $75.10 \pm 19.16$ & $1.98 \pm 0.22$ & Treatment Group III \\
\hline $12.81 \pm 4.09$ & $90.80 \pm 26.88^{4}$ & $143.0 \pm 55.92^{2}$ & $61.30 \pm 20.38$ & $1.63 \pm 0.09^{1}$ & Treatment Group IV \\
\hline
\end{tabular}

Values are means \pm SD. Calculated from $n=10$ in each group, ${ }^{1} p=0.001,{ }^{1} p=0.006$ and ${ }^{1} p=0.024$ compared to treatment Group I (control group), II and III (ANOVA), ${ }^{2} p=0.001$ and ${ }^{4} p=0.030$ compared to treatment Group I (control group) (ANOVA), ${ }^{3} p=0.032$ compared to treatment Group I (control group) (ANOVA), Treatment Group I (TG I) received drink water daily for 5 day (control group), Treatment Group II (TG II) received $0.9 \mathrm{mg} / \mathrm{kg}$ peppermint oil daily for 5 days, Treatment Group III (TG III) received $27 \mathrm{mg} / \mathrm{kg}$ peppermint oil daily for 5 day, Treatment Group IV (TG IV) received $60 \mathrm{mg} / \mathrm{kg}$ peppermint oil daily for 5 day.

Table 3. Comparison of Serum Alanine Transaminase (ALT), Apartate Tranaminase (AST), Alkaline Phosphotase (ALP) and Gamma Glutamyl Transferase (GGT) in Treatment Groups Pre- and Post- Immobility Stress

\begin{tabular}{|c|c|c|c|c|c|c|c|c|}
\hline & $\begin{array}{c}\text { T G I } \\
\text { Pre- IS }\end{array}$ & $\begin{array}{c}\text { T G I } \\
\text { Post- IS }\end{array}$ & $\begin{array}{c}\text { T G II } \\
\text { Pre- IS }\end{array}$ & $\begin{array}{c}\text { T G II } \\
\text { Post- IS }\end{array}$ & $\begin{array}{c}\text { T G III } \\
\text { Pre- IS }\end{array}$ & $\begin{array}{c}\text { T G III } \\
\text { Post- IS }\end{array}$ & $\begin{array}{c}\text { T G IV } \\
\text { Pre- IS }\end{array}$ & $\begin{array}{c}\text { T G IV } \\
\text { Post- IS }\end{array}$ \\
\hline \hline $\begin{array}{c}\text { MDA } \\
(\mathrm{nmol} / \mathrm{ml})\end{array}$ & $1.91 \pm 0.20$ & $2.13 \pm 0.40$ & $1.85 \pm 0.08$ & $2.05 \pm 0.24^{1}$ & $1.70 \pm 0.07$ & $1.98 \pm 0.22^{2}$ & $1.40 \pm 0.13$ & $1.63 \pm 0.09^{3}$ \\
\hline $\begin{array}{c}\text { ALT } \\
\text { (IU/L) }\end{array}$ & $95.20 \pm 36.90$ & $104.20 \pm 61.91$ & $115.85 \pm 40.79$ & $99.80 \pm 29.50$ & $121.20 \pm 31.18$ & $75.10 \pm 19.16^{4}$ & $127.50 \pm 36.76$ & $61.30 \pm 20.38^{5}$ \\
\hline $\begin{array}{c}\text { AST } \\
(\mathrm{IU} / \mathrm{L})\end{array}$ & $89.10 \pm 28.12$ & $76.60 \pm 22.48$ & $90.40 \pm 27.50$ & $102.0 \pm 13.98$ & $136.60 \pm 12.98$ & $123.30 \pm 37.89$ & $157.20 \pm 28.79$ & $143.0 \pm 55.92$ \\
\hline $\begin{array}{c}\text { ALP } \\
(\mathrm{IU} / \mathrm{L})\end{array}$ & $155.20 \pm 37.12$ & $135.60 \pm 41.04$ & $132.20 \pm 18.50$ & $120.0 \pm 30.42$ & $129.0 \pm 36.54$ & $103.10 \pm 37.60$ & $116.60 \pm 10.66$ & $90.80 \pm 26.88^{6}$ \\
\hline $\begin{array}{c}\text { GGT } \\
(\mathrm{IU} / \mathrm{L})\end{array}$ & $13 . .04 \pm 4.93$ & $10.61 \pm 4.19$ & $15.42 \pm 8.35$ & $12.41 \pm 5.35$ & $17.43 \pm 7.59$ & $12.71 \pm 4.59$ & $18.99 \pm 6.51$ & $12.81 \pm 4.09^{7}$ \\
\hline
\end{tabular}

Treatment Group I (TG I) received drink water daily for 5 day (control group), Treatment Group II (TG II) received $0.9 \mathrm{mg} / \mathrm{kg}$ peppermint oil daily for 5 days, Treatment Group III (TG III) received $27 \mathrm{mg} / \mathrm{kg}$ peppermint oil daily for 5 day, Treatment Group IV (TG IV) received $60 \mathrm{mg} / \mathrm{kg}$ peppermint oil daily for 5 day, IS: immobility stress, ${ }^{1} \mathrm{P}=0.026,{ }^{2} \mathrm{P}=0.001$, ${ }^{3} \mathrm{P}<0.001,{ }^{4} \mathrm{p}=0.001,{ }^{5} \mathrm{p}<0.001,{ }^{6} \mathrm{p}=0.011$ and ${ }^{7} \mathrm{p}=0.011$.

during dose-dependent peppermint oil metabolism could not inhibit AST, ALT and GGT activities and inhibits the ALP activity. There are a number of reports which indicates many adverse effects of spearmint to induce oxidative stress [26]. It has also been shown to develop severe histopathological malformations in liver tissues of rats [27]. According to Mimica-Dukic et al., [28], the free radical scavenging capacity of $M$. piperita oil was high. In their experiment, $M$. piperita reduced the radical generator 2, 2-diphenyl-1picrylhydrazyl (DPPH) by $50 \%$ and inhibited the generation of the $\mathrm{OH}$ radical. Rats given daily oral doses of $83 \mu \mathrm{L} / \mathrm{kg}$ peppermint oil for 28 days had significantly increased ALP level when compared with control group, but no increase in GGT or ALT [29]. Menthol administered to rats by gavage at 200,400 and $800 \mathrm{mg} / \mathrm{kg}$ for 28 days significantly increased the absolute and relative liver weights and the vacu- 
olization of hepatocytes at all doses, although no sign of encephalopathy was observed [30]. Menthone given orally to rats at 200,400 and $800 \mathrm{mg} / \mathrm{kg}$ for 28 days increased liver weight [19]. In a separate study, forty-eight male Wistar rats were used, and peppermint oil solution was prepared and daily given to the rats for 30 days as drinking water. Their findings showed that liver function tests, including AST and ALT activities and thiobarbituric acid reactive substance (TBARS) were measured. AST and ALT activities and the TBARS level were increased when compared with the control group. Histopathological evaluation of experimental groups revealed a mild to severe degree of hepatic damage when compared to the control group [31]. Alkaline phosphatase is commonly used as a relatively nonspecific indicator of hepatic injury $[32,33]$. It is therefore possible that chronic treatment with peppermint oil resulted in some degree of hepatic impairment, although no other parameters of liver function or liver morphology were impaired [30]. It has been shown previously that extracts of Mentha piperita (from which peppermint oil is derived) can increase ALP activity in irradiated rats [34] and that rats administered pulegone (a component of peppermint oil) for 28 days had increased plasma ALP activity without significant histopathology of the liver [28]. A dose-dependent increase in ALP has also been shown in rats administered menthone, another component of peppermint oil, for 28 days. Components of peppermint oil, namely pulegone $(80-160 \mathrm{mg} / \mathrm{kg}$ ) and menthol or menthone (200-800 mg/kg), administered to rats for 28 days have been shown to produce liver histopathological changes and changes in liver function $[19,20]$. In another study following treatment with peppermint oil resulted in a significant increase in ALP levels, but not in GGT or ALT. There were no significant changes in liver enzyme activities following acute treatment with peppermint oil. However, there were no changes in rat liver histology after any of the treatments with peppermint oil. In human cultured hepatoma cells, the percentage of dead cells was not affected by low concentrations $(0.05 \mathrm{~mL} / \mathrm{L})$ of peppermint oil compared with vehicle controls. However, there was a significant increase in the percentage of dead cells with higher concentration of peppermint oil $(0.5 \mathrm{~mL} / \mathrm{L})$ [22]. Our results are in accordance with the previous studies that the serum lipid peroxidation level has been decreased [29]. There are several studies, which show an increment in serum lipid peroxidation levels [27, 33]. Our results are also correlated with the previous studies that the serum ALT and AST has been increased [25] but our findings are not in agreement with other studies [30, 33]. The reduction of enzyme activities suggest that immobilization stress may increase MDA production in the serum of immobilized mice. Davydov et al., [35] suggested that immobilization stress stimulates free radical generation in the liver of both adult and old rats. These results indicate that MDA levels shown to be higher after immobilization stress than before in mice which were given peppermint oil. Lipid peroxidation markers (MDA and TBARS) are known to be increased in stress conditions in plasma [36], erythrocyte [37-39] and different tissues [40-45] of animals. Our results in agreement with previous study [36].The reduction of enzyme activities and elevation of MDA suggest that immobilization stress increase MDA production in serum of mice. When we compared enzyme activities in higher concentrations of peppermint oil (27 and $60 \mathrm{mg} / \mathrm{kg}$ ) before and after immobilization stress, the significant amount of decreased enzyme activities were observed in the serum of mice. This result may suggest that, MDA level is higher in immobilization stress group than in the un-immobilized animals in serum and this results show that enzyme activities decreased after immobilization stress. We may also suggest that generated MDA may damage enzymes (proteins) that are produce in the liver; therefore, it can lower enzyme activity. Immobilization stress can be a model for investigating the alterations occurring in liver enzymes. According to our results, exposure to immobilization stress ( $4 \mathrm{~h} /$ day for 5 days) may lead to increment of free radical generation which may have changed liver enzyme activities, and lipid peroxidation elevation in serum of mice. This result may suggest that, MDA level is higher in immobilization stress group than in the unimmobilized animals in serum and these results also show that enzyme activities decreased after immobilization stress. Using effective dose of peppermint oil is probably reduces the effect of immobilization stress on liver enzymes. Further studies are needed to clarify the mechanism of stressdependent free radical generation and its effects on the oxidative modifications in different tissues.

\section{CONFLICT OF INTEREST}

None declared.

\section{ACKNOWLEDGEMENT}

The authors would like to thank the personnel at the Biochemistry and Metabolic Research Center, Golestan University of Medical Sciences for providing for their cooperation and assistance in the handling of experiments.

\section{REFERENCES}

[1] Said, O.; Khalil, K.; Fulder, S.; Azaizeh, H. Ethnobotanical survey of medicinal herbs of the Middle Eastern region. J. Ethnopharmacol., 2002, 83, 251-265.

[2] Farnsworth, N.R.; Soejarto, D.D. Potential consequence of plant extinction in the United States on the current and future availability of prescription drugs. Econ. Bot., 1985, 39, 231-240

[3] Soejarto, D.D. Biodiversity prospecting and benefit-sharing: perspectives from the field. J. Ethnopharmacol., 1989, 51, 1-15

[4] Elvin-Lewis, M. Should we be concerned about herbal remedies? J. Ethnopharmacol., 2001, 75, 141-164

[5] Chan, K. Some aspects of toxic contaminants in herbal remedies. A review. Chemosphere, 2003, 52, 1361-1371

[6] Abu-Irmaileh, B.E.; Afifi F.U. Herbal medicine in Jordan with special emphasis on commonly used herbs. J. Ethnopharmacol., 2003, 89, 193-197

[7] Pak, E.; Esrason, K.T.; Wu, V.H. Hepatotoxicity of herbal remedies: an emerging dilemma. Prog. Transplant., 2004, 14, 91-96

[8] Saad, B.; Azaizeh, H.; Said, O. Tradition and perspectives of Arab herbal medicine: a review. Evid. Based. Complement. Alternat. Med., 2005, 2, 475-479.

[9] Clark, R.J.; Menary, R.C. Variations in composition of peppermint oil in relation to production areas. Econ. Bot., 1981, 35, 59-69.

[10] Blanco, M.C.S.G.; Ming, L.C.; Marques, M.O.M.; Bovi, O.A. Drying temperature effects in peppermint essential oil content and composition. Acta. Hortic., 2002, 569, 95-98.

[11] Pino, J.A.; Borges, P.; Martinez, M.A. et al. Essential oil of Mentha piperita L. grown in Jalisco. J. Essent. Oil Res., 2002, 14, 189-190.

[12] Ruiz del Castillo, M.L.; Santa-Maria, G.; Herraiz, M.; blanch, G.P. A comparative study of the ability of different techniques to extract mentol from Mentha piperita. J .Chromatogr. Sci., 2003, 41, 38538 . 
[13] Xup, Jia.W.; Bi, L.; Liu, X.; Zhao, Y. Studies on components and qualityof essential oil from Mentha piperita L. produced in Xinjiang, China. Chem. Ind. Forest. Prod., 2003, 23, 43-45

[14] Zhang, X. WHO Traditional Medicine Strategy 2002-2005. World Health Organization: Geneva, Switzerland, 2002.

[15] Dubick, M.A. Historical perspectives on the use of herbal preparations to promote health. J. Nutr., 1996, 116, 1348-1354.

[16] Stickel, F.; Egere, G.; Seitz, H.K. Hepatotoxicity of botanicals. Public Health Nutr., 2000, 3, 113-124.

[17] Liu, J.H.; Chen, G.H.; Yeh, H.Z.; Huang, C.K.; Poon, S.K. Entericcoated peppermint-oil capsules in the treatment of irritable bowel syndrome: A prospective, randomized trial. J. Gastroenterol., 1997, 32, 765-768.

[18] El Nahhal, Y. Contamination and safety status of plant and food in Arab countries J. Appl. Sci., 2004, 4, 411-417.

[19] Madsen, C.; Wurtzen, G.; Cartensen, J. Short-term toxicity study in rats dosed with menthone. Toxicol. Lett., 1986, 32, 147-152.

[20] Thorup, I.; Wurtzen, G.; Carstensen, J.; Olsen, P. Short term toxicity study in rats dosed with pulegone and menthol. Toxicol. Lett., 1983, 19, 207-210.

[21] Draper, H.H; Hadley, M. Malondialdehyde determination as an index of lipid peroxidation. Methods. Enzymol., 1990, 186, 421431

[22] Satoh, K. Serum lipid peroxide in cerebrovascular disorders determined by new colorimetric method. Clin. Chim. Acta., 1987, 90, $37-43$.

[23] Thomas, L. Alanine Transaminase(ALT), Aspartate Transaminase(AST). In: Thomas L, Ed. Clinical Laboratory Diagnostics. $1^{\text {st }}$ ed. Frankfurt: TH -books Verlagsgeselischft. 1998, 55-65.

[24] Thomas, L. Clinical Laboratory Diagnostics. $1^{\text {st }}$ ed. Frankfurt: THbooks Verlagsgeselischft. 1998, 136-146.

[25] Thomas, L. Clinical Laboratory Diagnostics. $1^{\text {st }}$ ed. Frankfurt: THbooks Verlagsgeselischft. 1998, 80-86.

[26] Akdogan, M.; Wnc, I.; Oncu, M.; Karaoz, E.; Delibas, N.W. Investigation of biochemical and histopathological effects of Mentha piperita L. and Mentha spicata L. on kidney tissue in rats. Hum. Exp. Toxicol., 2003, 22, 213-219.

[27] Akdogan, M.; Ozguner, M.; Aydin, G.; Gokalp, O. Investigation of biochemical and histopathological effects of Mentha piperita Labiatae and Mentha spicata Labiatae on liver tissue in rats. Hum. Exp. Toxicol., 2004a, 23, 21-28.

[28] Mimica-Dukic, N.; Bozin, B.; Sokovic, M.; Mihajlovic, B.; Matavulj, M. Antimicrobial and antioxidant activities of three Mentha species essential oils. Planta Med., 2003, 69, 413-419.

[29] Vo, L.T.; Chan, D.; King, R.G. Investigation of the effects of peppermint oil and valerian on rat liver and cultured human liver cells. Clin. Exp. Pharmacol. Physiol., 2003, 30, 799-804.

[30] Thorup, I.; Wurtzen, G.; Carstensen, J.; Olsen, P. Short term toxicity study in rats dosed with pulegone and menthol. Toxicol. Lett., 1983b, 19, 207-210.

[31] Akdogan, M.; Ozguner, M.; Aydin, G.; Gokalp, O. Investigation of biochemical and histopathological effects of Mentha piperita L. and
Mentha spicata L. on liver tissue in rats. Hum Exp Toxicol. 2004b, 23, 21-28.

[32] Settaf, A.; Zahidy, M.; Elimadi, A. et al. S-15176 reduces the hepatic injury in rats subjected to experimental ischemia and reperfusion. Eur. J. Pharmacol., 2000, 406, 281-92.

[33] Rosser, B. ; Gores, G. Liver cell necrosis: Cellular mechanisms and chemical implications. Gastroenterology., 1995, 108, 252-275.

[34] Samarth, R.M.; Goyal, P.K.; Kumar, A. Modulatory effect of Mentha piperita (Linn.) on serum phosphatases activity in Swiss albino mice against gamma irradiation. Ind. J. Exp. Biol., 2001, 39, 479-482.

[35] Davydov, V.V.; Zakharchenko, I.V.; Ovsyannikov, V.G. Free radical processes in the liver of adult and old rats during stress. Bull. Exp. Biol. Med., 2004, 137, 139-142.

[36] Liu, J.; Wang, X.; Shigenaga, M.K.; Yeo, H.C.; Mori, A.; Ames, B.N. Immobilization stress causes oxidative damage to lipid, protein, and DNA in the brain of rats. FASEB J., 1996, 10, 1532-1538.

[37] Gumuslu, S.; Sarikcioglu, S.B.; Sahin, E.; Yargicoglu, P.; Agar, A. Influences of different stress models on the antioxidant status and lipid peroxidation in rat erythrocytes. Free Radic. Res., 2002, 36, $1277-1282$

[38] Sahin, E.; Gumuslu, S.; Ozturk, O.; Abidin, I.; Yargicoglu, P.; Agar, A. Marked changes in erythrocyte antioxidants and lipid peroxidation levels of rats exposed to acute, repeated and chronic restraint stress. Pharmazie., 2004, 59, 961-964.

[39] Ozturk, O. ; Gumuslu, S. Age-related changes of antioxidant enzyme activities, glutathione status and lipid peroxidation in rat erythrocytes after heat stress. Life Sci., 2004, 75, 1551-1565.

[40] Giralt, M.; Gasull, T.; Hernandez, J.; Garcia, A.; Hidalgo, J. Effect of stress, adrenolectomy and changes in glutathione metabolism on rat kidney metallothionein content: comparison with liver metallothionein. BioMetals., 1993, 6, 171-178.

[41] Bian, J.S.; Wang, Y.L.; Li, D.X. Immobilization stress induced changes of ventricular electric stability in damaged heart depends on the extent of free radical damage. Shengli Xuebao., 1997, 49, 526-530.

[42] Seckin, S.; Alptekin, N.; Dogru-Abbasoglu, S.; Kocak-Toker, N.; Toker, G.; Uysal, M. The effect of chronic stress on hepatic and gastric lipid peroxidation in long-term depletion of glutathione in rats. Pharmacol. Res., 1997, 36, 55-57.

[43] Sahin, E.; Gumuslu, S. Cold-stress-induced modulation of antioxidant defense: role of stressed conditions in tissue injury followed by protein oxidation and lipid peroxidation. Int. J. Biometeorol., 2004a, 48, 165-171.

[44] Sahin, E.; Gumuslu, S. Alterations in brain antioxidant status, protein oxidation and lipid peroxidation in response to different stress models. Behav. Brain Res., 2004b, 155, 241-248.

[45] Dhir, A.; Padi, S.S.; Naidu, P.S.; Kulkarni, S.K. Protective effect of naproxen (non-selective COX-inhibitor) or rofecoxib (selective COX-2 inhibitor) on immobilization stress-induced behavioral and biochemical alterations in mice. Eur. J. Pharmacol., 2006, 535, $192-198$

(c) Marjani et al.; Licensee Bentham Open.

This is an open access article licensed under the terms of the Creative Commons Attribution Non-Commercial License (http://creativecommons.org/licenses/by-nc/3.0/) which permits unrestricted, non-commercial use, distribution and reproduction in any medium, provided the work is properly cited. 